\title{
European Competition Policy in time of crisis. To be or not to be
}

\author{
Liviana Andreea Nimineţ, Universitatea Vasile Alecsandri din Bacău
}

\begin{abstract}
:
It is a known fact that Competition and all the policies implied by it have a positive impact on Economy. But what happens when financial crisis strike? Has Competition Policy an autoregulating power or it must be helped by International Institution? What is the road to be followed in time of recession?
\end{abstract}

\section{Key words:}

Competition policy, crisis, competition law

\section{Crisis background}

When talking about crisis the first thing that comes in mind is the question "What went wrong?". The current crisis has its roots in a series of enormous strategic errors made by the banks and other financial institutions. In "technical" words the main reason was the balance sheets (assets and liabilities) of banks relative to their own capital that expended, not over the last year, but over the past decade. As a result of this expansion some huge global imbalances appeared (Asian saving and Western borrowing to spent) ${ }^{1}$ combining with the steady growth, low interest rates, low inflations. Plain said, these institutions borrowed far too much given their low capital base, and, when the asset price bubble began to burst, they were caught out. The peak of this was reached by the selling and purchasing of opaque credit default derivatives between financial institutions. What happened then is very plastic expressed by Bruce Lyons $^{2}$ : the rapid demand growth suppressed the power of competition to select only the fittest to survive in the same way the unlimited food in the animal kingdom does. The financial crisis originating in the USA quickly spread to the rest of the world with confidence receding inter-bank lending rarefied and a serious credit crunch. Financial institutions throughout the world got into trouble, and over time the crisis in the financial markets has caused wide-spread financial difficulties across the world.

\section{Competiton policy and the financial and economic crisis}

All the economic theories support the fact that competition is desirable because it increases the welfare of consumers and contributes to efficiency in economic activity. Competition is defined as the rivalry between individual firms. Rivalry ensures that only the most efficient and innovative firms are in the market and thus competition is an ongoing process that works through using the company resources, entry and exit in the market and innovation. It is difficult to quantify how much does an efficient competition affect the productivity and the Economy in general, but a number of

\footnotetext{
${ }^{1}$ John Vickers, The financial crisis and competition policy: some economics ,The global competition policy magazine, December 2008 (1)

${ }^{2}$ In the Paper: Competition Policy, Bailouts and economic crisis
} 
extensive studies have found that stronger competition is associated with higher productivity and efficiency. In the same way that it is clear that competition in business has a positive impact, it has also been established that competition restrictions may cause great damage to the public and the economy.

There are several reasons for which one can say that a recession has a big harmful potential for competition and all the policies supported by it.

A. In order for competition policy to work the markets need time to evolve and became efficient. In other words the entry of new and efficient ones as well as the exit of the inefficient is only a part of competition policy's goal.

B. The competitive markets generally produce better value for consumers, but during a recession the short run survival actions take over and usually the exit of the un-fitted firms may be more expensive for the society. This also comes from the fact that the competition's benefits do not appear immediate and are less visible while the costs of the existence of business, employees and consumers are more up-front.

C. The recession determines a public pressure exercised over the political power in order to intervene and rescue the failing firms, counteract the unemployment and consumer vulnerability. If in times of a benign macroeconomic environment in the principal market places the laissez faire stance prevails, in times of recession state's intervention is expected. Neelie Kroes, the Europeam Commissioner for Competition stated that laissez faire is not a good solution for a society: "It was John Ralston Saul who said that $<<$ unregulated competition is just a naïve metaphor for anarchy $>>$ - we don't need that. What we need are regulated markets. The challenge is to maximize our prosperity by finding the most efficient ways to regulate them"

In times of crises competition law becomes particularly important. In earlier crises, proposals have come forward calling for weaker competition laws. In order to be able to assess the rationale of such a standpoint, it is helpful to look at experiences and evidence from earlier economic setbacks, recessions or depressions. Lessons can be learned from the Great Depression and how it was dealt within United States. Research has shown that weakening competition laws as a tool to combat economic difficulties may have the opposite effect and works to prolong the crisis. It is important to keep this in mind when governments take actions in order to limit the negative effects of the current crisis.

The current global crisis has profoundly affected the availability and cost of credit to the world's households and businesses. Being basically a crisis in trust this credit crunch impacted almost all European countries by a quick and deep contraction of the economies. Stock prices are down between 50 per cent and 90 per cent since the peak in early 2007. Unemployment rates have risen and will first start to level in 2010. Inflation remains low, however, but a real fear of deflation still exists. Initiatives to remedy the effects of the crisis include expansive fiscal policy measures and tax cuts, credit packages for households and industries as well as bank rescue packages. In these circumstances, crises is likely to determine companies to have anticompetitive conducts. A distressed economic environment is a situation that monopolies and cartels may take advantage of. It may also be in the advantage of no market power suppliers that in time of market crisis may achieve substantial market power and thus increase prices for a long time while their rivals being in the incapacity of reaction. The crisis may pose pressure for the legalization of export cartels or even recession cartels (for saving the distressed domestic firms and provide them with an export market advantage) as well as to the allowance the mergers (by definition, anticompetitive) for saving the failing companies.

\footnotetext{
${ }^{3}$ The Economic Club Toronto, Competition, the crisis and the road to recovery, March ,2009
} 


\section{The policy and measures of the EU Commission in respect to the financial crisis}

A wide spread reaction was determined as the financial crisis hit Europe, and this reaction involved not only ECB, but national governments and the European Commission as well. Much of the initiative to deal with the crisis in a concerted way has come from the EU Member States. At later stages the ECOFIN has actively developed common principles to guide Member States in their reactions to the crisis, resulting in a concerted action plan, which was subsequently endorsed by the European Council of mid October 2008. The European Commission has played an active role in the design and implementation of the financial recovery plan. The Commission had the explicit support of the European Council which confirmed that the EC competition rules, also referring to the principles of single market and State aid rules, should be applied despite the exceptional circumstances. As noted by Gerard (2008), the Commission's role was extremely important in: a) providing legal certainty to economic operators b) acting as stabilizing force through the crisis, and in c) preventing negative spillover effects from individual Member States actions in relation to the crisis.

The legal certainty is built on two principles and two phases of the crisis. The principles are "clarity in the applicable legal framework" and "the rapidity of action". The stabilizing role was emphasized in the flexibility of approved measures, while strictly adhering to the legislation, and the negative spillovers were targeted with prevention of a widespread systemic crisis.

The first temporal phase of the crisis, between September 2007 and September 2008, derived from the supreme crisis reaching Europe, which was unable however to induce widespread fears of a systemic crisis. During this first phase of the crisis, the Commission tackled the individual cases according to Article 87 (3) (c) of the EC Treaty and the "Community Guidelines on State aid for rescuing and restructuring firms in difficulty."

The second phase of the crisis revealed the potential severity of the crisis at hand. It started as fears of a systemic crisis arose, partly due to the "reorganization" bankruptcy filing of Lehman Brothers. The eroding confidence in the banking sector from October 2008 resulted in a severely restricted access to liquidity. There were doubts whether the "Guidelines" would still provide an appropriate framework to tackle the crisis, as the systemic nature of the crisis was now realized to threaten sound financial institutions as well.

In this phase the importance of "rapidity of action" was further emphasized. In early November 2008, the European Union's Heads of State and Government agreed on the need for a coordinated response to the crisis. The Commission's European Economic Recovery Plan, was a response to the Member States coordinated effort to deal with the crisis. ${ }^{4}$ The plan intends, among other things, to stimulate demand and confidence, and to boost long-term competitiveness. It proposes a countercyclical macroeconomic response to the crisis in the form of a set of actions to support the real economy. Some of the proposed measures include State aid.

The Commission, and the state aid control as an integral part of the EU's competition policy, plays key roles in this countercyclical macroeconomic response. The latest overviews of actions taken confirm that EU State aid policy has indeed provided a framework for coordinated and rapid implementation of national measures. The role of the Commission as a stabilizing force is highlighted in that, while showing some reluctance to compromise the interpretation of $\mathrm{EC}$ competition law principles, it has

\footnotetext{
${ }^{4}$ Communication from the Commission to the European Council, A European Economic Recovery Plan; COM(2008) 800 of 26 November 2008
} 
shown that the current legal framework is rather flexible in the face of exceptional circumstances.

During the second phase of the crisis, the Commission approached the resolution of the financial crisis in three steps:

1. The Banking Communication adopted on 13 October $2008^{5}$

2. Recapitalization Communication of 5 December $2008^{6}$

3. Impaired Assets Communication of 25 February $2009^{7}$

The Banking Communication allowed rescue operations in order to stop or prevent runs on financial institutions. In this context, Art 87 (3) (b) of the EC Treaty was considered to be an appropriate legal basis for State intervention. The Recapitalization Communication identified a set of standards and safeguards allowing Member States to recapitalize banks to ensure adequate future levels of lending. Concerns about adequate lending volumes were raised in view of the reluctance shown by fundamentally sound banks to continue lending at usual volumes and conditions.

The Impaired Assets Communication provides the framework for a so called "cleanup phase" of financial institutions' balance sheets by removing toxic assets and underperforming loans. This phase is assumed to require restructuring in the market, but is considered being an essential step in order to restore confidence in the financial sector and the economy.

In December 2008 the Commission adopted a "Temporary Framework", with measures available to the end of 2010, to allow Member States to mitigate or remedy the effect of the credit crunch on the real economy in minimally distortive way. The two main objectives pursued by the temporary measures are ${ }^{8}$ :

1. To unblock bank lending to companies and thereby guarantee continuity in their access to finance

2. To encourage companies to continue investing in the future, in particular in a sustainable growth economy including the development of green products.

According to this temporary framework, Member States may grant, under certain conditions:

a. a lump sum of aid up to $€ 500,000$ per company for the next two years, to relieve them from current difficulties

b. state guarantees for loans at a reduced premium

c. subsidized loans, in particular for the production of green products (meeting environmental protection standards early or going beyond such standards)

d. risk capital aid up to $€ 2.5$ million per SME per year (instead of the current $€ 1.5$ million)in cases where at least 30 per cent (instead of the current 50 per cent) of the investment cost comes from private investors.

The need for and implementation of financial aid has been large and widespread. By April 2009 , the European Commission approved 49 separate financial aid schemes and was investigating 11 more. These schemes concerned 19 of

\footnotetext{
${ }^{5}$ OJ C 270, 5.10.2008 Communication from the Commission - The application of the State aid rules to measures taken in relation to financial institutions in the context of the current global financial crisis, p. 8-14.

${ }^{6}$ OJ C 10, 15.1.2009, Communication from the Commission- The recapitalization of financial institutions in the current financial crisis: limitation of the aid to the minimum necessary and safeguards against undue distortions of competition, p.2-10

7 OJ C 72, 26.3.2009, Communication from the Commission on the Treatment of Impaired Assets in the Community banking sector, of 25 February 2009, p.1

${ }^{8} \mathrm{OJ}$ C $16,22.1 .2009$, The consolidated version, integrating the amendments adopted by the Commission on 25 February 2009, p. 1-9 (published in OJ C 83, 7.4.2009, p. 1-15).
} 
the Member States (among which were all 15 pre-2004 Member States). According to the Commission the temporary framework was respected, and by May, the Commission authorized a total of 37 measures in 16Member States under the Framework.

\section{References:}

E. Carletti, Background Note on competition anf financial markets prepared for OECD Global Competition Forum, February 2009- DAF(COMP)/2009(2)

D. Gerard, Managing the Financial crisis in Europe: Why competition law is a part of the solution not the problem, Global Competition Magazine, December 2008

B. Lyons, Competition Policy, Bailouts and the Economic Crisis, Centre for Competition Policy, University of East Anglia, February 2009 ( $1^{\text {st }}$ draft $)$

M. Motta, Competition Policy: theory and practice, Cambridge Publishing House, 2004

J. Vickers, The financial crisis and the competition policy: Some Economics, Global Competition Policy Magazine, December 2008

Communication from the Commission to the European Council, A European Economic Recovery Plan; COM(2008) 800 of 26 November 2008

Oficial Journal C 270, 5.10.2008 Communication from the Commission - The application of the State aid rules to measures taken in relation to financial institutions in the context of the current global financial crisis

Oficial Journal C 10, 15.1.2009, Communication from the Commission- The recapitalization of financial institutions in the current financial crisis: limitation of the aid to the minimum necessary and safeguards against undue distortions of competition

Oficial Journal C 72, 26.3.2009, Communication from the Commission on the Treatment of Impaired Assets in the Community banking sector, of 25 February 2009

Oficial Journal C 16, 22.1.2009, The consolidated version, integrating the amendments adopted by the Commission on 25 February 2009 